\title{
CIVIL-MILITARY RELATIONS DURING THE PERIOD OF THE JUSTICE AND DEVELOPMENT PARTY IN TURKEY
}

\author{
ADALET VE KALKINMA PARTISI DÖNEMINDE TÜRKIYE'DE SIVIL-ASKER ILIŞKILERI
}

\author{
Yrd. Doç. Dr. Uğur Burç YILDIZ
}

İzmir Üniversitesi Uluslararası İlişkiler Bölümü. burc.yildiz@izmir.edu.tr

\begin{abstract}
In recent years, under Justice and Development Party rule, intervention by the Turkish military into politics via formal and informal mechanisms has decreased. This article aims to explain why the Turkish military's influence in politics through both formal and informal mechanisms has been decreasing under Justice and Development Party rule since the 2002 elections. We argue that the two main reasons for the military's decreasing role in politics in this period are the impact of the reforms intended to democratize civilmilitary relations within the context of the Turkey's harmonization packages to European Union acquis and the alleged Ergenekon organization and coup plans. In the first stage, the formal mechanisms of the military decreased substantially with the introduction of the harmonization packages in 2003 and 2004. However, the military continued to intervene in politics largely through informal mechanisms such as speeches, press statements and declarations given by the senior members of the military on domestic and foreign policy issues. Since 2008, with the beginning of the second stage, as a result of the alleged Ergenekon organization and coup plans, the military has been inclined, to a great extent, to use informal mechanisms not as a way of intervening in politics but rather to protect its own public prestige.
\end{abstract}

Keywords: Civil-Military Relations, Formal Mechanisms, Informal Mechanisms, Justice and Development Party, EU Harmonization Packages, Ergenekon.

\section{INTRODUCTION}

The military, which played a significant role in the foundation of the Turkish Republic, has been the primary protector and upholder of the secular and unitary characteristics of the regime. In pursuit of this mission, the military disrupted democratic political life through two direct (May 27, 1960 and September 12, 1980) and two indirect (March 12, 1971 and February 28, 1997) coups. The military also provided itself with various exit guarantees ${ }^{1}$ in exchange for a return to a democratic political regime through institutional regulations following these coups. Therefore,

\footnotetext{
${ }^{1}$ The military juntas generally determine the conditions for thier extrication from government and gain some guarantees of a share of power in the coming democratic political order. Such guarantees are usually called as "exit guarantees" in civil-military relations studies. It is possible to group these guarantees under five headings: tutelary powers, reserved domains, manipulation of the electoral process, irreversibility of actions of the military regime, and amnesty or indemnity laws (Özbudun, 2000; p. 106).
} 
the military became one of the most important actors in Turkish politics, particularly through the formal mechanism of the National Security Council (Milli Güvenlik Kurulu, MGK) by force of the exit guarantees. Apart from formal mechanisms, the military also sustained its influence in politics through informal mechanisms, which include statements, press releases and declarations from high-ranking officers.

Turkey's Europe adventure, which started with the Association Agreement signed between the European Economic Community and Turkey in 1963, gained momentum when Turkey was declared a candidate country by the European Union (EU) at the 1999 Helsinki Summit. Turkey began to democratize its legislation by taking into account a number of issues stressed in the EU's Progress Reports. This process accelerated under the Justice and Development Party (Adalet ve Kalkınma Partisi, AKP) after general elections held on November 3, 2002. The AKP adopted harmonization packages (reform packages) in 2003 and 2004. Some of the reforms in these packages were aimed at the democratization of civil-military relations, and as a result, the AKP substantially prevented the military from affecting politics through the use of formal mechanisms. In particular, after the MGK was reduced to a mere advisory body, the military had no possibility of interfering in politics through this mechanism. However, the military continued to have an impact on politics significantly through informal mechanisms between 2004 and 2008. Particularly, interference continued in the issues of internal threats such as political Islam and $\mathrm{PKK}^{2}$ terrorism. In 2008, as a result of the investigations and arrests concerning the alleged Ergenekon organization, which is claimed to include many retired and active officers who organized to overthrow the AKP government, and military coup plans, to a considerable extent the military began using informal mechanisms to defend itself against these charges and uphold its reputation in the public's eye. As a result, the military largely withdrew from intervening into politics of the AKP.

This article begins by giving a historical background of the establishment of AKP, its ideology and election victories, and the military's view of the AKP. The second section of this paper deals with how the military significantly lost its power on formal mechanisms after the adoption of several EU reforms in 2003 and 2004 by the AKP. Following an analysis of the reforms and discussion of social legitimacy of the military, the article then focuses on the issues such as political Islam and PKK terror, which the military interfered through its informal mechanisms. The third section deals with how the military has refrained from interfering in the politics of the AKP since 2008 as a result of the investigations and arrests of military officers within the scope of the alleged Ergenekon organization and military coup plans. It also concentrates on how the military has been trying to defend itself vis-à-vis the alleged Ergenekon cases and military coup plans through informal mechanisms. The conclusion provides a general evaluation and some suggestions regarding how civilmilitary relations in Turkey could be more democratic.

\footnotetext{
2 Partiya Karkaren Kürdistan- Kurdistan Workers' Party
} 


\section{THE JUSTICE AND DEVELOPMENT PARTY: AN OVERVIEW}

The Virtue Party (Fazilet Partisi, FP) was shut down on June 22, 2001 by the Constitutional Court for the unsecular activities of its members. Following its ban from politics, the reformist wing of the party, led by Recep Tayyip Erdoğan, accused the FP for not establishing communication and consensus with the largest segment of society and suggested the establishment of a new party. Consequently, the reformist wing of FP established the AKP on August 14, 2001. The traditionalist wing of the FP, which supported the continuance of the now-defunct party's former policies, established the Felicity Party (Saadet Partisi, SP) on July 20, 2001. The AKP, however, aimed at addressing to masses and accordingly brought individuals from very broad political and social backgrounds together for their Founders' Committee (Akdoğan, 2004; p. 9).

From the beginning, the AKP has distinguished itself from previous political Islamic parties ${ }^{3}$ through ideological differences. For example, the AKP refused the idea that the party was a continuation of previously existing political Islamic parties; indeed, party officers even refrained from referring to themselves as "Muslim democrats" (Hale \& Özbudun, 2010; p. 20). Instead, Erdoğan defined the political identity of the AKP as that of "conservative democrat." What he meant as the political mentality of conservative democracy is as follows:

"According to our identity of conservative democracy, which provides the basis for our new political ntality, politics is a field of consensus. We acknowledge the diversity and differences of social sphere in political field and invite all parties of politics to consensus on every issue. We think that differences of ideas are natural and brings us richness. Based on tolerance and lenience provided by democratic pluralism, social and cultural diversities should bring politics a different flavor. We also predicate that participatory democracy will improve itself by providing opportunity of representation for differences and participating in political process" (AKP, 2003; October 18).

After the elections of November 3, 2002, the AKP came to power with $34.3 \%$ of the vote. It is argued that AKP Chairman Erdoğan was able to receive this many votes as a result of the statements he made on human rights, freedoms, economic development and Turkey's integration into the EU during the campaign. The election results were also a reaction from the public who suffered as a result of the 2001 economic crisis in Turkey (Çaha, 2003; p. 102), as most people were looking to a new government to steer them out of a rocky economy. Increasing economic growth, as seen in rising per capita income and growing public investments in health and transportation, boded well for the AKP's growth: the party increased its share of the vote to $46.5 \%$ in the July 22,2007 elections and gained $49.8 \%$ of the vote in the June 12, 2011 elections (Aydın-Düzgit, 2012; p. 12).

\footnotetext{
${ }^{3}$ These are the National Order Party (Milli Nizam Partisi, 1970-1971), the National Salvation Party (Milli Selamet Partisi, 1972-1981), the Welfare Party (Refah Partisi, 1983-1998), the Virtue Party (Fazilet Partisi, 1997-2001) and the Felicity Party (Saadet Partisi, 2001- ).
} 
The AKP, which has governed Turkey since 2002, experienced profound disagreement with the military. For its part, the military has taken a dim view of AKP and has always seen it as a threat to the secular state regime because its executives were former political Islamists and the party supported religious sects and congregations. In addition, despite the fact that the AKP has spoken highly and frequently of democratization and Westernization, the party's statements have always been perceived by the military as a form of deception used to shield its true intentions to turn Turkey into a sharia state through a secret agenda. AKP, after coming to power, put into practice reforms that would bring the civil-military relations close to a democratic model within the scope of the EU harmonization process. The purpose of the party was to provide the subordination of the military to the civilians in order to dominate the decision-making in politics. As will be examined in the next section, as a result of constitutional amendments and harmonization packages, the military lost many of the formal mechanisms that had enabled it to interfere in politics, which in turn gave the Armed Forces to pursue its influence in politics via informal mechanisms.

\section{THE FIRST STAGE: REFORMATION OF THE FORMAL MECHANISMS (2003- 2004) AND THE CONTINUATION OF THE MILITARY'S ROLE IN POLITICS THROUGH INFORMAL MECHANISMS (2004-2008)}

For many years the MGK was the most important formal mechanism that enabled the military to exert its influence on Turkish politics (Cizre- Sakallıoglu, 1997; pp. 157- 161). In addition, the State Security Courts (Devlet Güvenlik Mahkemesi, DGM), the authority of the General Staff to select members to the Board of Higher Education (Yüksek Ögretim Kurulu, YÖK), Article 35 of the Internal Service Law of the Turkish Armed Forces (Türk Silahlı Kuvvetleri, TSK) and the status of the General Staff being responsible to the Prime Ministry were significant political privileges bestowed upon the military. Turkey, after acquiring EU candidate status in the Helsinki Summit in December 1999, has since instituted many reforms aimed at democratization of the country, with the ultimate goal of obtaining full membership to the EU. A significant proportion of these reforms have addressed the democratization of civilmilitary relations.

One of the most important changes that the 1961 Constitution that was written in the aftermath of the coup brought forth, in terms of civil-military relations, was the foundation of the MGK. According to the 1961 Constitution, the MGK was envisaged to convene under the chairmanship of the President, with the participation of ministers laid down by law along with the Chief of General Staff (CGS) and his representatives. Its scope of task was defined as lending assistance and delivering opinions to the Cabinet to make decisions and to ensure coordination on national security.

The main purpose of the establishment of the MGK was to guarantee the intervention of officers in politics regarding all security issues (Harris, 1988; p. 183). Amendments to the 1961 Constitution made during the period of de facto pressure 
of the military junta between 1971 and 1973 increased the power of the military. For example, changing the expression "Force Representatives" to "Force Commanders," amending the word "inform," as related to the authority of the MGK, to "recommend," and removing the phrasing "lending assistance" all furthered the military's purview in government. While the issue of ministers participating in the MGK was not determined and was left to the law in the 1961 Constitution, the 1982 Constitution fixed the number of ministers by overtly expressing who the participating ministers would be. Also in the new constitution it was ensured that the Commander of the Turkish Gendarmerie Forces would participate in the Council and thus the number of civilian members would not surpass the number of the military participants (Çelik, 2007; p. 247). On the other hand, the power of the MGK's decisions was increased by adding the expression, "the decisions deemed necessary by the Council, about the precautions to be taken, are taken notice of by the Cabinet primarily." With the 1982 Constitution, an expression, in which many issues such as "keeping the peace and prosperity of the society", was added to the national security definition related to the duties of the MGK, which had already been defined in broad terms.

In 2001, as a result of reforms made by the three-party coalition comprised of the Democratic Left Party, the Nationalist Movement Party and the Motherland Party, the number of civilian members participating in the MGK was increased and thus the MGK's influence on the Cabinet was reduced. In this respect, the number of civilian members was increased by adding the Minister of Justice and Deputy Prime Ministers to the MGK, the latter of which was comprised of five military members (CGS and four Force Commanders) and four civilian members (the Prime Minister, the Minister of Interior, the Minister of Foreign Affairs and the Minister of Defense). In addition, a statement referring to any MGK decision that read "would primarily be taken into consideration by the Cabinet" was changed to "would primarily be evaluated by the Cabinet." Under AKP rule, with the seventh harmonization package, the method of electing the MGK Secretary General from among civilian members was ensured; the authority of the CGS on selecting and assigning the MGK Secretary General was transferred to the Prime Minister; the monthly meetings of the MGK were resolved to be held bi-monthly; and the authority of the MGK Secretary General was seriously narrowed. Most importantly, while the authority of the MGK was reduced to an advisory role on issues such as determining, assigning and applying the national security policy of the state, an overt initiative was presented to the Prime Minister and the Cabinet in applying these decisions. Thus, the MGK was legally changed into an advisory body.

Within the scope of regulations made after the 1971 memorandum, which increased the political autonomy of the military, the DGMs were established and entrusted with "the task of trying the crimes related directly to the national security and crimes against the republic, with its qualities such as the indivisible integrity of the state with the country and the nation, and having a free democratic order determined in the constitution." The DGMs, which were abolished in 1976, were again established with the 1982 Constitution. By affiliating military members to the 
civilian judges and public prosecutors in the DGMs, significant judicial authority was given to the military in resolving political crimes related to the security of the state (Yazıcı, 2009; p. 91). In democratic judicial systems, it is a principle that civilians would stand trial only in civilian courts. However, DGMs, with their considerably broad authority, favored the principle of "protecting the state" over that of the "principle of justice" by protecting the state against individuals and opposing social groups, which is contrary to democratic judicial systems (Insan Hakları Derneği, 1997, October 10). With the eighth harmonization package adopted on May 7, 2004, however, the DGMs were abolished, and therefore a very important step was taken in terms of criminal justice.

The 1982 Constitution passed a decree declaring that YÖK was to be "established with members that were directly elected by the President from among candidates determined by the universities, the Cabinet and General Staff, and whose number, qualities and election procedures were determined by the law, giving priority to professors who served as rectors or faculty members." The related Article brought an important privilege to the military authority in education by granting authorization to the General Staff, in addition to universities and the Cabinet, in determining YÖK candidates. In this respect, the military was endowed with an important opportunity to direct and control higher education to ensure that it was within the confines of the secular and unitary character of the regime. With the eighth harmonization package, however, the military's influence on education was weakened by removing the provision allowing for the selection of one member of YÖK by the General Staff (Secretariat General for European Union Affairs, 2007; p. 18).

In 1935, the expression "the duty of the military is to protect the Turkish motherland and the Turkish Republic according to the constitution" was added to Article 34 of the Internal Service Law of the TSK, and actually this wording constituted the basis for the military coups during the multi-party period. This Article was added to Article 35 of the Internal Service Law of TSK dated January 4, 1961. One of the most important regulations in terms of civil-military relations brought about by the 1961 Constitution was again connecting the General Staff to the Prime Ministry, which was first responsible to the Minister of Defense in 1949. Thus, the place of the military bureaucracy in the constitutional system was reinforced (Çelik, $p$. 154). This situation caused the CGS to be placed before the Minister of Defense in state protocol and provided political power to the CGS in the bureaucratic hierarchy. ${ }^{4}$ Debates on abolishing both regulations continue today among the Turkish public and political parties. ${ }^{5}$

\footnotetext{
${ }^{4}$ In EU countries, the Chief of Staff is connected to the Minister of Defence. However, in Turkey, the Chief of Staff is placed fourth in the state protocol after the President, the President of the Turkish Grand National Assembly and the Prime Minister.

5 The AKP government made several amendments to the 1982 Constitution that were approved in a referendum on September 12, 2010 in order to curtail the military's political and judicial impact. Accordingly, the constitutional reform limited the jurisdiction of military courts to "military service and military duties." Under the new system, civilian courts will deal with crimes against state security, the constitutional order and the functioning of this order. The amendments to the Constitution opened
} 
Following the reforms that were introduced during the AKP governments that curtailed the military's formal power, the TSK referred to informal mechanisms to exert its power in politics. Indeed, the Turkish military does not wield its power to intervene in politics only through those mechanisms determined by the law. In addition to these legal mechanisms, many unofficial factors originating from Turkish history and culture - in other words, informal factors - help the military have a say in politics. As Ümit Cizre asserted, "The power of the military in Turkey is at a level that cannot be measured only by formal mechanisms" (Cizre, 2004; p. 185). Thus, highranking officers of the Turkish military have become influential in politics through statements, press releases and declarations (informal mechanisms) on certain occasions.

In principle, the appreciation and acceptance of these informal mechanisms by the public, and their power to prompt politicians in the direction of opinions stated by officers, have their roots in the social legitimacy of the military. In fact, the Turkish military takes this legitimacy from historical and cultural factors. After the collapse of the Ottoman Empire, the most organized power structure transferred to the modern Turkish Republic was not the political parties, civilian bureaucracy, press or educational institutions, but the military. The people who organized the National War of Independence, who founded the Republican Regime and who restructured the new Turkish state were soldiers, including such well known names as Mustafa Kemal Atatürk, the founder of Republic of Turkey and his fellow İsmet Inönü. The role played by the military in the foundation of the nation-state established the belief that the military was the state itself.

One of the important elements of the collective identity of Turkish society is military values. Issues related to the military play an important role in defining Turkish society and render Turkish society distinguishable (Demirel, 2004; p. 354). For instance, the discourse of a "military nation," soldier sendoff ceremonies, children having their pictures taken in military uniform and the wishes of some disabled youngsters to fulfill even one day of military service reveal military values that are embedded in the collective identity of Turkish society. Another example of these military values is the frequent use of the slogan "Every Turk is born a soldier" in daily speech, in the statements of public officials and intellectuals, in school books and during military service itself (Altınay, 2004; p. 13).

A basic sociological theory is that in the case that some mechanisms in a society fail to fulfill their function, other mechanisms step in. In this respect, another factor that gives the military social legitimacy is society's belief that political and civil mechanisms do not function properly. For instance, the government's general malaise in responding to the economic crisis in 2000 was what prompted a call to duty from the president of the İstanbul Chamber of Commerce for the MGK. In the

dismissals of military staff by the Supreme Military Council to judicial review. The Chief of General Staff and the commanders of the army, air force, navy and gendarmerie will be tried before a high tribunal for any offences committed in the course of their official duties. The constitutional provision providing immunity for perpetrators of the 1980 coup d'état was deleted from the Constitution. 
same fashion, calling the military for assistance instead of the police in circumstances where the social order breaks down reveals that law enforcement by police is generally mistrusted. The belief that the military fulfills all duties with success and minimizes the clientelism also plays an important role in increasing the social legitimacy of the military in Turkey where many people consider politicians to be corrupt (Demirel, p. 358). It is for these reasons that the public generally relies on the Turkish military first before politicians or government bodies.

While the power of formal mechanisms was reduced as a result of the constitutional and legal reforms made after the initiation of Turkey's EU candidacy, it was not possible to change the informal mechanisms. An important point that attracts attention in the EU's 2006 Progress Report for Turkey is the emphasis on the necessity that the statements by the military authorities "should only concern military, defense and security matters and should only be made under the authority of the government" (European Commission, 2006; p. 7). Thus, the EU manifested these standards to prevent the influence of informal mechanisms on politics in Turkey.

As a result of these cultural and emotional ties of the society to the military, the informal mechanisms, such as speeches, declarations and press statements, have been effective in Turkish politics. Here are some examples of the informal mechanism through which the military succeeded in exerting its force in politics between 2004 and 2008. Since the foundation of the Turkish Republic, religious education has been the most important source of conflict between the military and conservatives. In its 2002 election campaign the AKP promised to remove the university exam coefficient difference for students of Vocational Religious High Schools. In 2003, the AKP proposed the coefficient regulation along with a draft YÖK law that allowed headscarves to be worn in universities. Debates on the draft continued until May 2004 and caused tension between the government and the military. After statements given by the Commanders and particularly a declaration published by the General Staff on its own website on May 6, 2004, which stated that the draft was against secular education principles, (Genelkurmay Başkanlığı, 2004, May 6) the government suspended the draft and did not revive it. Even Prime Minister (PM) Erdoğan confessed, "We are not, as the government, ready to pay the price for this" (Erdoğan:YÖK'ü Zorlamayız, 2004). ${ }^{6}$

\footnotetext{
${ }^{6}$ On February 7, 2008, PM Erdoğan managed to make a constitutional amendment to allow women for wearing the headscarves in universities with the support of the MHP, the key opposition party. However, as a result of the secularist Republican People's Party's (Cumhuriyet Halk Partisi, CHP) application, the Constitutional Court annulled the amendment on the grounds that removing the ban was against the secularism principle of the constitution. After winning a referandum in September 2010, the AKP government issued a statement saying it would support any student expelled or disciplined for covering her head ('Quiet End,' 2010, December 31). This support paved the way for the YÖK to take action. In October 2010, Yusuf Ziya Özcan, the then President of the YÖK, in a seeming contradiction of the Constitutional Court ruling of 2008, notified the universities that instructors may no longer take action against students wearing headscarves ('YÖK Head Gives Guarantee,' 2010, October 13). After this notification, all universities across Turkey abandoned the offical headscarves ban. In addition, Özcan totally abolished university exam coefficient difference on November 30, 2011 ('YÖK Ends,' 2011,
} 
Along the same line, further conflict arose when Deputy CGS Illker Başbuğ demanded in July 2005 that the Anti-Terrorism Act to be revised to increase the efficiency of the military in counter-terrorism (Genelkurmay Başkanlığı, 2005, July 19). Following Başbuğ, CGS Hilmi Özkök emphasized that the military was fighting terrorism with limited authority (Genelkurmay Başkanlığı, 2005, August 5). The AKP and the Ministry of Foreign Affairs argued against increasing security forces' authority via the Anti-Terrorism Act, particularly regarding Article 8 of the Act which regulated written and spoken propaganda, and emphasized that there should be no retreat from democratization. However, as a result of the pressure from the military, in June 2006 the government enacted the amendments demanded by the military in a way that covered propaganda crimes. Thus, the policy of the AKP government had undergone a direct change with the influence of the military.

In November 2005, as a result of a bomb placed in former PKK member Seferi Yılmaz's bookstore in the town of Şemdinli in the Hakkari province, one person died and six people were injured. The townspeople held two members of the Gendarmerie responsible for the incident and even tried to lynch them (Şemdinli Gergin, 2005, November 10). While debate on who exactly planted the bomb continued, the government declared that it would be decisive in finding the perpetrators and no one would be protected (Kim Yapmışsa Bedelini Ödeyecek, 2005, November 11). However, after the Van Public Prosecutor Ferhat Sarıkaya, who prepared the indictment, added Yaşar Büyükanıt, Commander of the Land Forces, because of his statement on one of the perpetrators as "I know him, he's a good boy" (Bila, 2005, November 12), the government gave up its decisive attitude in the beginning as a consequence of the statements of CGS Özkök protecting Büyükanıt, and turned Prosecutor Sarıkaya into a target. In this instance, the decisive policy of the AKP government underwent a direct change. After a press conference at which the CGS called to duty anyone with a constitutional responsibility to do so, the Supreme Board of Judges and Prosecutors dismissed Prosecutor Sarıkaya from his profession. After the risk of the investigation heading towards the top of the military was parried, the Şemdinli case progressed rapidly. At the first trial held in the military court on December 14, 2007, the defendant sergeants, Ali Kaya and Özcan Ildeniz, were released.' In the EU's 2006 Progress Report for Turkey, declarations made by the high- ranking officers of the military on the Şemdinli Indictment were criticized (European Commission, 2004, p. 7).

Another example of the military affecting politics via informal mechanisms includes the presidential elections of 2007. In general, the interest of the military in presidential elections is grounded in the authority of the President to assign the bureaucrats who play the leading role in the operation of the state system. In 2007, PM Erdoğan nominated Minister of Foreign Affairs Abdullah Gül, who is himself loyal

December 1). The military could not oppose these moves because of its passive position as a result of the continuing investigations on Ergenekon organization and military coup plans.

${ }^{7}$ However, the Şemdinli case had continued. On January 10, 2012, Van Heavy Penal Court No. 3 sentenced the defendants to 39 years 10 months and 27 days of imprisonment each on charges of "constituting an illegal organisation", "homicide" and "attempting homicide". 
to an Islamic lifestyle, for President. This drew strong reaction from the military, which published its views in the form of a secularist warning on the General Staff's website on the night of the first round of elections on April 27, 2007. The message, perceived by many as a coup threat, caused the Constitutional Court to render the first election round results invalid. The government then called for early general elections on account of the fact that the politics was deadlocked. In this respect, the military had a strong influence on the process of presidential elections.

More examples also manifest that the military continued to have influence in politics through informal mechanisms during this period. In the presence of continuing PKK terrorism and persistent demands of the United States (U.S.) that Turkey should cooperate with the Kurdish groups in Northern Iraq against terrorism, on February 14, 2007, PM Erdoğan has spoken as follows: "Steps could be taken to improve the relations with the Regional Kurdish government in Northern Iraq. Why not? Just so may this convergence bring welfare and peace and cause positive developments. If the step we take would bring peace for us, peace for them we are in for this" (Kürt Gruplar ile Yakınlaşırız, 2007 February 15). Contrary to this statement of PM Erdoğan that the government might negotiate with the Kurdish government on fighting with the PKK, CGS Yaşar Büyükanıt, in a press conference in Washington on February 16, 2007, said, "I do not negotiate with the people who give support to PKK," adding that the two Kurdish groups in Northern Iraq supported the PKK (PKK Destekçisi Kürt Liderlerle Görüşmem, 2007, February 17). After the trenchant reaction of CGS Büyükanıt, PM Erdoğan declared that a negotiation on the level of Prime Ministers and Ministers of Foreign Affairs was not in question, but only meetings of a technical level (commissions) could be possible, (Bila, 2007, February 28). PM Erdoğan's last statement shows that his first opinion, that it was possible to negotiate with the Kurdistan Regional Government, was changed directly by the influence of CGS Büyükanit's statement. Yet, as retired general Edip Başer, the former CounterTerrorism Coordinator of Turkey, mentioned, the technical meetings of Turkey with Massoud Barzani and Jalal Talabani had been ongoing for 30 years ('Edip Başer,' 2007, February 17).

On April 12, 2007, CGS Büyükanıt emphasized the need for a cross-border military operation, implying that the Kurdistan Democratic Party of Massoud Barzani was a natural ally with the PKK. He said, "Should a military operation into Northern Iraq be made? Yes, it should. The incident has two dimensions. First, when you look at the incident as a soldier, yes, it should be made. Will it be useful? Yes, it will be useful. The second dimension is political. In order to make an operation across the border we need a political decision to emerge. The Turkish Armed Forces can make these operations if it is called for duty legally" ('Orgeneral Büyükanıt,' 2007, April 13). Against this call from CGS Büyükanıt, PM Erdoğan stated that he did not agree with the opinion that a cross-border operation would be useful. He said, "Is the fight against the 5000 terrorists inside Turkey finished that we will deal with 500 terrorist in Northern Iraq? We should resolve the terrorist shelters in Turkey first" (Önce Türkiye Sonra Kuzey Irak, 2007, June 13). However, it has been suggested that the reason PM Erdoğan found the cross-border operation unfavorable was that he wanted to win the 
Kurdish vote in Turkey before the early general elections of July 22, 2007. Another reason was that PM Erdoğan did not want to confront the U.S. and the Kurds in Northern Iraq before the general elections (Bila, 2007, June 13). After AKP's coming to power after the elections, CGS Büyükanıt rephrased the policy of the military regarding the cross-border operation by saying, "We are standing by our words stated on 12 April" ('12 Nisan'da,' 2007, July 31). After this, the government sent a motion giving the authority to make cross-border operations to the Turkish Grand National Assembly (Türkiye Büyük Millet Meclisi, TBMM). Despite the warning from the then U.S. President George W. Bush not to enter Iraq, the motion was adopted in the TBMM with 507 votes in favor (Bush: Irak'a Girmeyin, 2007 October 18).

\section{THE SECOND STAGE: MILITARY'S RETREAT FROM POLITICAL INTERVENTION (2008- )}

Investigations that started in 2007 and accused many retired and active officers of being members of the Ergenekon Organization and preparing coup plans are of unprecedented scale in Turkey's history. Since early 2008, the investigations have forced the General Staff to retreat to a defensive position. In this respect, the General Staff gave all its concentration to the queries of the investigations, and moreover, its statements about the AKP governments' policies have nearly come to an end. The military did not even make any statements about issues included in the draft constitution, including changes allowing high-ranking military officers to be tried in civilian courts, widening the definition of national identity to cover citizens from different ethnic origins and religions and enabling Kurdish to be taught in state schools as a second language (Hale \& Özbudun, p. 92). Additional evidence proving that the military has become averse to intervening in politics was its silence concerning the government's lifting of the ban on headscarves in universities and its introduction of the Democratic Initiative Project, which was designed to increase the civic freedoms of Kurds. However, this silence was later breached when the military issued a reactionary statement after a show of PKK supporters. As part of the Democratic Initiative Project, the PKK was turning over a group of its members to Turkish authorities at the Habur border gate on October 19, 2009. As part of this process the PKK supporters' show of happiness when welcoming the members of PKK, who were supposedly not involved in crimes, at the Habur border gate spurred nationalist sentiment across Turkey and in particular among the families of soldiers who were killed during the clashes with the PKK. Ferit Güler, Secretary General of the General Staff, called this incident unacceptable and warned, "Any kind of behavior or attitude which may trigger polarization, separation or conflicts in the country must be avoided. Democracy is not a system without defense"' ('Military,' 2009, October 23).

The Ergenekon investigation, which began with the discovery of hand grenades in a tenement district of İstanbul in June 2007, has become one of the greatest investigations in Turkey's history. According to prosecutors carrying out the investigation, Ergenekon is a massive organization that has interpenetrated Turkish life and devoted itself to overthrowing the AKP government. The investigation has divided Turkish public opinion. According to AKP proponents, Kurdish nationalists 
and some left-wingers, the investigation was part of the eradication of the Turkish deep state. For the AKP opponents, the investigations were seen as part of the government's plan to get rid of secularists who opposed the AKP's policies (Jenkins, 2009; pp. 9- 10). While public opinion is split on the investigation, the General Staff showed its first important reaction against the detention of retired and active officers by calling on the Turkish nation to present legal and democratic reaction (Hava Kuvvetlerindeki Soruşturma Yürüyor, 2008, July 19).

Nokta, a weekly news journal, published the coup diaries allegedly belonged to Özden Örnek, the then Commander of the Naval Forces, between August 2003 and August 2005 in its issue of March 29, 2007- April 4, 2007. The coup plan, endowed with the code name "Sarıkız," entered into the first indictment of the Ergenekon investigation prepared by the Istanbul Public Prosecution in July 2008. In the prosecution's second indictment in March 2009, it was claimed that there were three other coup plans with the codes names Ayışı̆̆ı (Moonlight), Yakamoz (Seasparkle) and Eldiven (Glove) that were detailed in CDs belonging to Şener Eruygur, former Commander of the Gendarmerie Forces (8 Mart 2009 Tarihli Ergenekon Iddianamesi, pp. 267- 269).

While the Ergenekon investigation was continuing, Turkey's agenda was shaken by one action plan and two coup plans, revealed by the newspaper Taraf. These were the Action Plan to Fight Reactionaryism (or, as it is called in some newspapers and visual media, "Plan for Finishing off AKP and Fethullah Gülen Sect") ${ }^{8}$ and the coup plans Kafes (Cage) and Balyoz (Sledgehammer). On June 12, 2009, Taraf published the Action Plan to Fight Reactionaryism. The paper claimed that this plan was prepared in the General Staff's headquarters by its Operations Division. Moreover, it included the signature of Colonel Dursun Çiçek. In a news article, it was claimed that the aim of the plan, which dated back to April 2009, was to stop the support and the actions of the government and the Gülen sect because both wanted to establish sharia law in Turkey (AKP ve Gülen'i Bitirme Planı, 2009, June 12). The General Staff Military Court initiated an investigation after the Taraf publication and imposed a broadcast ban on news regarding the Plan. As a result of the debates about the Plan, CGS Başbuğ, on 26 June 2009, broke new ground, unprecedented in Turkish political life, and organized a press conference, taking 36 generals and admirals with him. In this press conference, Başbuğ said, "Turkey, for almost two weeks, has lost unnecessary energy over a document, which was not much more than mere piece of paper." CGS Başbuğ also asserted that the document was

\footnotetext{
8 The most powerful of the sects in Turkey is a group known as the "Fethullah Gülen Community" led by Fethullah Gülen. Gülen places great emphasis on education in order to form a class of intellectuals that will exceed the order brought by the Turkish revolution. With this purpose Gülen founded many private educational institutions with the privatization and marketization of the educational system in 1983. However, Gülen schools are not limited to Turkey and more than 300 hundred colleges and 7 universities were opened around the world. In these schools 6000 teachers give service to more than 26,500 students. Because of their actions and opinions regarding increasing the power of political Islam, the military has always considered the Gülen community and its extensions abroad a threat to secular regime.
} 
prepared to apply an asymmetrical psychological war on the TSK via the opposition media in order to wear out the TSK (Psikolojik Savaş İçin Kağıt Parçası, 2009, June 27).

While discussions continued regarding the alleged Action Plan to Fight Reactionaryism and whether Colonel Dursun Çiçek had signed the document or not, the November 19, 2009 edition of Taraf published the news that prosecutors had found the Kafes (Cage) Coup Plan, allegedly prepared by the Naval Forces. Taraf reported that the documents were found while following tracks of ammunition found in the Poyrazköy district of İstanbul in 2009. In this plan, it was claimed that the junta in the Naval Forces wanted to finish off the AKP by targeting non-Muslims (Kod Adı Kafes, 2009, November 19). A month after the publication by Taraf, CGS Başbuğ organized press conference on board at the Oruç Reis Frigate and stressed that the asymmetrical war on the Turkish military continued and stated, "We are disturbed from the situation we are in now" (İçinde Bulunduğumuz Süreçten Rahatsızız, 2009, December 18).

On January 20, 2009 Taraf published an article about the Balyoz (Sledgehammer) Coup Plan, which was allegedly prepared by the junta led by Çetin Doğan, the then Commander of the First Army, in 2003. The article claimed that the plan described the performance method of the coup that would follow the decalartion of a state of siege. In addition, the article contained very serious claims including the organization of bombing attacks on the Fatih and Beyazıt Mosques in İstanbul on Friday to kill worshipers in order to create suitable grounds for a military coup (Darbenin Adı Balyoz, 2010, January 20). Soon after the publication of the news, CGS Başbuğ broke his silence on the allegations about this Plan in the First Army Command in İstanbul and stated that the time of military coups was over for Turkey. As to the claims in the coup plan to organize bomb attacks on mosques in İstanbul, he reacted by saying, "How come a military which gives its soldiers assault by making them shout 'God God!' can think of bombing the house of God? It is not fair to accuse military in such a way. I damn the ones who claim these" (Sabrımızın Sınırı Var, 2010, January 26). Taraf delivered the documents, consisting of almost 5000 pages, to the prosecution nine days after publication. This was followed by the broadest detention operations against soldiers in the history of Turkey. Seventeen retired generals, four active admirals and twenty-six officers, including former force commanders, were detained in one day (Cemal, 2010; p. 488).

After Illker Başbuğ's retirement, Işık Koşaner became CGS on August 27, 2010. CGS Koşaner did not make any statements about the policies of the government during his term of office. However, he continued to defend the military against investigations carried out on alleged Ergenekon and coup plans by using informal mechanisms, especially via press statements published on the General Staff's website. He made these statements in a milder manner compared to former CGS Başbuğ. Incidentally, an unexpected development occurred in July 2011. PM Erdoğan, in an interview with CGS Koşaner on July 29, 2011, stated that the government would not approve of the promotion of detained officers in the Supreme Military Council, which would start on August 1, 2011. After this, CGS Koşaner pointed out that a total of 250 officers, 173 active and 77 retired, were 
detained and these detentions were against universal law principles, fairness, justice and conscientious values.

On the same day CGS Koşaner, along with the Land, Air and Naval Force Commanders, resigned by requesting their retirement. While Turkey confronted the mass resignations of its commanders for the first time, public opinion turned fearful over the possibility that the country was heading toward a serious crisis. However, the government weathered the storm in a very short time by assigning a new command echelon, including the CGS. The EU viewed the event as "Turkey becoming a more democratic country in which democratic institutions have control over military decisions" (AP: Türkiye'de Demokrasi Güçleniyor, 2011, July 30).

The military's inclination to use informal mechanisms to maintain its public prestige has continued under the term of CGS Necdet Özel who came into office on August 4, 2011. In January 2012, Özel made a statement to journalist Fikret Bila in which he responded to claims regarding the luxurious life of officers in Hadımköy Military Prison. While speaking to Bila, Özel also briefly referred to political issues such as his disapproval of the teaching of the Kurdish language in state schools, the long detention periods for officers, the Kurdistan Regional Government's lack of support for Turkey's fight against PKK terrorism, and a political discussion on abolishing the Military Court of Appeals and the Supreme Military Administrative Court (PKK'nın Adını Gündemden Sileceğiz, 2012, January 5). On May 5, 2012, Özel denied media reports that military training includes lectures covering coups and toppling the state administration. He stressed through the General Staff's website that the Turkish army does not give lessons at any level of military training that cover military coups, intervention in state administration or any lectures which could be perceived as such. Özel also pointed out that "The Turkish Armed Forces aim to train personnel in a way that takes the developments in the 21 st century into account, based on change and progress, enabling them to learn technological developments and use and command all superior technology arms systems" (Turkish Military Denies 'Coup Lecture', 2012, May 6).

The military's waning influence in politics did not come without its hardships. In fact, during the first year of CGS Özel's term of office, some staunch secularists tried to provoke the military to stage a coup against the AKP government. Ümit Kocasakal, the President of the Istanbul Bar Association, gave a very provocative speech on April 30, 2012 at Eskişehir Anatolian University in which he said, "We thought that we had a powerful army. We thought it would protect us. It is not Turkish Armed Forces anymore; it is Turkish Unarmed Forces. You are Turkish Unarmed Forces; that's why we are going to work nonstop" ('TSK Değil,' 2012, April 30). In addition, Cumhuriyet newspaper writer Bekir Çoşkun wrote a column entitled "Pasha" (general) on April 29, 2012. In his column, Çoşkun pointed out the similarity of the military shoulder patches to dog leashes and accused the Turkish military of being under the command of the AKP government (Çoşkun, 2012, April 29). General Staff reacted to these provocations from its website by a declaration that read as follows: "These claims and comments intend provocation and they try to debilitate the efforts, motivation, and morale of altruistic and heroic TSK members who 
perform their task in the best way that's possible...TSK will not be provoked and will continue to serve for our country and great nation tied to the parliamentary democratic system" (Genelkurmay Başkanlığı, 2012, May 3).

Uncharacteristically, Kemal Kılıçdaroğlu, leader of the secularist CHP, which kept its silence on the General Staff's former declarations against AKP governments, reacted to General Staff's declaration regarding provocations. Kılıçdaroğlu said a General Staff's declaration that targeted journalists is unacceptable in a democratic country. Kılıçdaroğlu also stressed that, from now on, the new CHP will counter the General Staff's declarations ('CHP Leader Says,' 2012, May 8). Interestingly, however, PM Erdoğan, who had criticized the military's political declarations several times, supported the declaration by stressing, "Such insults should not be tolerated by the people who occupy those ranks. They must not be left unanswered. The response they (the General Staff) gave was actually quite polite" ('Turkish Prime Minister,' 2012, May 9). These statements of PM Erdoğan and Kılıçdaroğlu showed that Turkish politicians could change their attitudes regarding the intervention of military in politics according to political conditions.

\section{CONCLUSION}

Turkey's experience with democracy has been a roller coaster ride, full of ups and downs. During the period of the multi-party system, which started when the Democratic Party (Demokrat Parti) replaced the governing CHP in the 1950 elections, Turkey witnessed two direct (1960 and 1980) and two indirect (1971 and 1997) military coups. According to military officers, these coups were carried out to protect the secular and unitary characteristics of the Turkish state. However, following each of these coups, the military strengthened its power through constitutional and legal amendments that transformed it into one of the most important actors in Turkish political life. Turkey under AKP rule, during which the EU accession process gained speed, actualized important institutional reforms in 2003 and 2004 in an attempt to democratize civil-military relations. As a result of these reforms, the military has largely lost its power to intervene in politics via formal mechanisms such as the MGK. It is argued that there is a need to form democratic structures that will ensure civilian control of the military to prevent it from influencing political life (Akay, 2009; p. 9). This approach is correct, but the formation of these democratic structures is not always sufficient to keep the military out of politics. This has been dramatically illustrated in the Turkish example. Indeed, the military influenced the policies of the AKP governments via informal mechanisms after the institutional reforms that were realized in 2003 and 2004. Since 2008, because of the alleged Ergenekon Organization and coup plans, the military has largely given up intervening in the policies of the AKP governments via informal mechanisms and has used these mechanisms instead to maintain its own public prestige.

As we have seen, the role of the military in Turkish politics through both formal and informal mechanisms has been decreasing since the AKP first came to power in 2002. However, Turkey still needs further institutional reforms such as the abolition of Article 35 of the TSK's Internal Service Law and connecting the General 
Staff to Ministry of Defense. These are the two most important remaining reforms in terms of democratization of the formal mechanisms. In addition, the Turkish military is still capable of showing its influence in politics through informal mechanisms. This influence cannot be curtailed by institutional reforms, because while the institutions themselves can be changed, it will take generations to change the culture of society. Therefore, as the EU has warned Turkey, statements, speeches and press statements by the military should only concern military, defense and security matters and should only be made under the authority of the government. With regard to Turkish politicians, we take the lessons from the reactions of PM Erdoğan and CHP leader Kılıçdaroğlu to the General Staff's declaration against the provocative statements of secularists in 2012, that they have to behave in accordance with democratic principles and reject the informal mechanisms of the military. Reforming the remaining formal mechanisms, following the principle of the EU on informal mechanisms and Turkish politicians' rejection of the military's informal mechanisms should pave the way for more democratic civil-military relations in Turkey.

\section{REFERENCES}

8 Mart 2009 Tarihli Ergenekon Iddianamesi', Retrieved May 20, 2010, From Cm.Ntvmsnbc.Com/DI/ Ergenekon/ 2.lddianame.Doc

12 Nisan'da Söylediğimiz Şeylerin Arkasındayız. (2007, July 31). Milliyet.

Akay, H. (2009). Demokratik Gözetim: Kurumsal Değerlendirme. In A. Bayramoğlu \& A. İnsel (Eds), Almanak Türkiye 2006- 2008 Güvenlik Sektörü Ve Demokratik Gözetim (Pp. 9- 12). İstanbul: Tesev Yayınları.

Akdoğan, Y. (2004). Ak Parti Ve Muhafazakar Demokrasi. İstanbul: Alfa Yayınları.

Akp. (2003, October 18). Başbakan Recep Tayyip Erdoğan Tarafından Tbmm'ye Sunulan 59'uncu Hükümet Programı. Retrieved March 2, 2010, From

Http://Www.Akparti.Org.Tr/Tbmm/Tbmmgrup/59hükümet\%20programı.Doc

Akp Ve Gülen'i Bitirme Planı. (2009, June 12). Taraf.

Altınay, A. G. (2004). The Myth Of The Military Nation: Militarizm, Gender And Education In Turkey. New York: Palgrave Macmillan.

Ap: Türkiye'de Demokrasi Güçleniyor.(2011, July 30). Radikal.

Aydın-Düzgit, Senem. (2012). No Crisis, No Change: The Third Akp Victory In The June 2011 Parliamentary Elections In Turkey. South European Society And Politics, 0, 1- 18.

Bila, F. (2005, November 12). Sezer: Türban Konusu Kapanmıştır, Milliyet

Bila, F. (2007, February 28). Kuzey Irak'taki Çelişki, Milliyet.

Bila, F. (2007, June 13). Erdoğan'ın Verdiği Mesajlar, Milliyet.

Bush: Irak'a Girmeyin. (2007, October 18). Milliyet.

Cemal, H. (2010). Türkiye'nin Asker Sorunu. İstanbul: Doğan Kitap.

Chp Leader Says Tsk Statement On Criticism Of Military Unacceptable. (2012, May 8). Todays Zaman.

Cizre, Ü. (2004). Türkiye'de Silahlı Kuvvetler'in Etkisi Ve Gücü Yalnızca Yasalarla, Kurumlarla Ve Kurullarla Ölçülemeyecek Büyüklüktedir. In H. Göktaş \& M. Gülbay (Eds), Kışladan Anayasaya Ordu, Siyasal Kültürde Tsk'nın Yeri (Pp. 184- 195). İstanbul: Siyahbeyaz Metis Güncel Yayınları.

Cizre-Sakallığlu, Ü. (1997). The Anatomy Of The Turkish Military's Political Autonomy. Comparative Politics, 29, 157- 161.

Çaha, Ö. (2003). Turkish Election Of November 2002 And The Rise Of Moderate Political Islam. Turkish Journal Of International Relations, 2, 95- 116. 
Çelik, S. (2007). Osmanlıdan Günümüze Asker Ve Devlet: Askeri Bürokrasinin Sistem Içindeki Yeri. İstanbul: Salyangoz Yayınları.

Çiçek: Şemdinli'de Soruşturmanın Sonucu Beklenmeli. (2005, November 11). Hürriyet.

Darbenin Adı Balyoz. (2010, January 20). Taraf.

Demirel, T. (2004). Türk Silahlı Kuvvetleri'nin Toplumsal Meşruiyeti Üzerine. In A. İnsel \& A. Bayramoğlu (Eds), Bir Zümre, Bir Parti, Türkiye'de Ordu (Pp. 345- 383). İstanbul: Birikim Yayınları.

Edip Başer Sert Konuştu: Abd Fantezi Peşinde. (2007, February 17). Milliyet.

Erdoğan: Kabile Reisiyle Görüşmem. (2007, June 7). Hürriyet.

Erdoğan: Yök'ü Zorlamayız. (2004, July 4). Radikal.

European Commission. (2004, October 6). 2004 Regular Report From The Commission On Turkey's Progress Towards Accession. Brussels, Sec(2004) 1201, \{Com(2004) 656 Final\}, Retrieved May 26, 2010, From

Http://Ec.Europa.Eu/Enlargement/Archives/Pdf/Key_Documents/2004/Rr_Tr_2004_En.Pdf

European Commission. (2006, November 8). Turkey 2006 Progress Report. Brussels, Sec(2006) 1390\{Com(2006) 649

Final\}, Retrieved May 26, 2010, From Http://Ec.Europa.Eu/Enlargement/Pdf/Key_Documents/2006/ Nov/Tr_Sec_1390_En.Pdf

Genelkurmay Başkanlı̆ı. (2004, May 6). Türkiye Büyük Millet Meclisi'ne Sunulan Yüksek Öğretim Kanunu Değişiklik Tasarısı Hakkında. Retrieved March 23, 2010, From Http:/Www.Tsk.Tr/10_Arsıv/10_1_Basin_Yayin_ Faaliyetleri/10_1_Basin_Aciklamalari/2004/Ba_07.Html

Genelkurmay Başkanlığı. (2005, August 5). Genelkurmay Başkanı Orgeneral Hilmi Özkök'ün Afganistan Uluslararası Güvenlik Yardım Kuvveti Türk Görev Grubu'nu Karşılama Töreni'nde Yaptıkları Konuşma. Retrieved October 31, 2009, From Http:/Www.Tsk.Tr/10_Arsiv/10_1_Basin_Yayin_Faaliyetleri/10_1_7_Konusmalar/2005/ İsafkarsilama_050805. $\mathrm{Html}$

Genelkurmay Başkanlığı. (2005, July 19). Bölücü Terörle Mücadelede İçinde Bulunulan Sürecin Değerlendirilmesi ToplantıSI. Retrieved November 2, 2009, From

Http:/Www.Tsk.Tr/10_Arsiv/10_1_Basin_Yayin_Faaliyetleri/10_1_6_Toplantilar/Temmuz2005/Ana.Html

Genelkurmay Başkanlı̆ı̆. (2006, March 20). Basın Açıklaması. Retrieved November 25, 2009, From Http:/Www.Tsk.Tr/10_Arsiv/10_1_Basin_Yayin_Faaliyetleri/10_1_Basin_Aciklamalari/2006/Ba_07.Html

Genelkurmay Başkanlığı. (2012, May 3). Basın Açıklamaları. Retrieved May 9, 2012, From Http://Www.Tsk.Trl 3_Basin_Yayin_Faaliyetleri/3_1_Basin_Aciklamalari/2012/Ba_01.Htm

Hale, W., \& Özbudun, E. (2010). Islamism, Democracy And Liberalism In Turkey: The Case Of Akp. London And New York: Routledge.

Harris, G. S. (1988).The Role Of The Military In Turkey In The 1980s: Guardians Or Decision Makers? In M. Heper \& Ahmet Evin (Eds.), State, Democracy And The Military in Turkey In The 1980s (Pp. 177- 200). Berlin And New York: Walter De Gruyter.

Hava Kuvvetlerindeki Soruşturma Yürüyor. (2008, July 19). Radikal.

Içinde Bulunduğumuz Süreçten Rahatsızız. (2009, December 18), Milliyet.

İnsan Hakları Derneği. (1997, October 10). Devlet Güvenlik Mahkemeleri'nin Kaldırıması İstemine Ilişsin Insan Hakları Derneği'nce Başlatılan Kampanyanın Basın Açıklaması Metni. Retrieved July 7, 2010, From Http://Www.Ihd.Org.Tr/Index.Php?Option=Com_Content\&View=Article\&ld=1024\&ltemid=202

Jenkins, G. (2009). Between Fact And Fantasy: Turkey's Ergenekon Investigation. Central Asia- Caucasus Institute Silk Road Studies Programme, Silk Road Paper, Baltimore: Johns Hopkins University.

Kim Yapmışsa Bedelini Ödeyecek. (2005, November 11). Sabah.

Kod Adı Kafes. (2009, November 19). Taraf.

Kürt Gruplar Ile Yakınlaşırız. (2007, February 15). Hürriyet.

Military And Hsyk React To Pkk Surrenders. (2009, October 23). Hurriyet Daily News.

Orgeneral Büyükanıt 'Kuzey Irak'a Girmeliyiz' Deyip Topu Hükümete Attı. (2007, April 13). Radikal.

Önce Türkiye Sonra Kuzey Irak. (2007, June 13). Milliyet. 
Özbudun, E. (2000). Contemporary Turkish Politics: Challenges To Democratic Consolidation. Colorado And London: Lynne Rienner Publishers.

Pkk Destekçisi Kürt Liderlerle Görüşmem. (2007, February 17). Hürriyet.

Pkk'nın Adını Gündemden Sileceğiz. (2012, January 5), Milliyet.

Psikolojik Savaş ļçin Kağıt Parçası. (2009, June 27). Radikal.

Quiet End To Turkey's College Headscarf Ban. (2010, December 31), Bbc News. Retrieved July 4, 2012, From Http://Www.Bbc.Co.Uk/News/World-Europe-11880622

Sabrımızın Sınırı Var. (2010, January 26). Milliyet.

Secretariat General For European Union Affairs. (2007). Political Reforms In Turkey. Ankara, M\&B Tanıtım Hizmetleri.

Şemdinli Gergin. (2005, November 10). Hürriyet.

Tsk Değil Silahsız Artık Kuvvetler. (2012, April 30). Star.

Turkish Military Denies 'Coup Lecture'. (2012, May 6).Hurriyet Daily News.

Turkish Prime Minister Urges Generals To Sue Columnist. (2012, May 9). Hurriyet Daily News.

Yazıcı, S. (2009). Demokratikleşme Sürecinde Türkiye. İstanbul: Bilgi Üniversitesi Yayınları.

Yök Ends University Exam's Coefficient System In Landmark Move. (December 1, 2011). Today's Zaman.

Yök Head Gives Guarantee To All Turkish Students On Headscarves. (October 13, 2010). Hürriyet Daily News, Retrieved July 4, 2012, From Http://Www.Hurriyetdailynews.Com/Default.Aspx?Pageid=438\&N=Yok-Head-GivesPersonal-Guarantee-To-All-Students-2010-10-13 